\title{
NOUS PLANS, NOUS MESTRES?
}

L'Escola de Mestres de Tarragona és a punt de formar part o d'incardinar-se en un projecte universitari ampli: la creació de la futura Facultat de Ciències de l'Educació i Psicologia. Aquesta, pel que sembla, s'allotjarà al Complex Educacional de la carretera vella de Valls, on ara només hi ha l'Escola. El conjunt formarà un bloc on hi haurà tres ensenyaments diferenciats, que seran les unitats de Psicologia, de Pedagogia -o de Ciències de l'Educació- i de Magisteri. Aqui s'hi encabirà la formació inicial del professorat il'ICE de formació permanent. Junts seran l'eix central de la formació del professorat de les comarques tarragonines en la nounaa Universitat Rovira i Virgili, universitat que, per altra part, en aquestes primeres passes dubtoses, sembla voler bescantar els estudis anomenats, tradicionalment, de lletres...

La reforma de l'espai anirà acompanyada, sobretot, de la configuració de nous plans, els quals, marcaran el perfil d'un mestre renovat, al voltant d'una carrera tramada a base de crèdits, on l'alumne tindrà una part d'actuació dissenyada per ell mateix. Les especialitats, d'altra banda, també seran noves, adaptades a les necessitats de l'avui i del demà proper.

La pregunta que es planteja en els àmbits de les Escoles de Mestres -no únicament a la nostra, per tant-, és si amb els nous programes es generarà un nou tipus de mestre. Un dels interrogants que s'hi veu és que probablement l'Escola perdi aquell caràcter professional que tenia, on alumnes i professors, de forma general, marcaven un segell del que havia de ser el futur mestre. En aquests darrers anys s'ha incidit i participat en un conjunt d'activitats extrascolars que han reflectit aquesta voluntat. S'ha entès que no n'hi havia prou amb les classes i s'ha potenciat el treball de tallers, de sortides, d'intercanvis, de xerrades amb especialistes, oferint temes nous, de partici- pació en la vida acadèmica... Ara, aquest perfil que agafaven els futurs mestres, veiem que pot quedar truncat si l'Escola queda engolida en aquest macroprojecte de Facultat. Si l'Escola no sap diferenciar-se d'aquesta estructura que ens ve damunt, l'essència del que ha de ser un professional-mestre, actiu, integrat a un país, crític, i sobretot il.lusionat, pot anarse'n en orris. Aquest, creiem, és el gran repte que presenta la futura Reforma. A part, és clar, que la pròpia formació de mestre no s'hauria de contemplar com a carrera terminal sense possibilitat de promoció

L'aspecte positiu també hi és, indubtablement. Els nous plans trenquen aquella estructura acadèmica farcida d'assignatures, d'horaris pleníssims, de treballets de cara a la galeria, de ser una continuació dels estudis de secundària. Els nous plans presenten l'al.licient de menys matèries, de més aprofundiment, de treball més actualitzat, amb matèries curriculars més properes a l'escola, de configurar-se un mateix un perfil diferenciador, d'integrar-se plenament en una estructura universitària de primera $i$, sobretot, de ser, de ple dret, una carrera universitària.

La pregunta, però, no queda resolta. Professors i alumnes opinem que benvinguda la Reforma, però aprofitant el que de bo hi havia fins ara, on el lligam continuï i l'alumne no quedi engolit en l'anonimat, on el mestre que formem sigui adaptable, versàtil i amb inquietuds. Si el professional en exercici es va fer a mitges a l'Escola de Mestres, ara voldríem que en sortís més complet, amb un bagatge de comprensió força sòlid, i on la seva empremta fos reconeguda arreu, pel bé d'uns alumnes que, sens dubte, necessiten esperits renovats de pensament i d'acció. S'aconseguirà? Només podem respondre que, junts, treballarem amb més ganes encara. 